\title{
NK combinations do not alleviate the effects of salt stress on gas exchange, photosynthetic pigments and growth of cotton (Gossypium hirsutum L.)
}

\author{
Francisco Wesley Alves Pinheiro ${ }^{1}$, Geovani Soares de Lima ${ }^{2 *}$, Hans Raj Gheyi ${ }^{3}$, Saulo Soares da Silva ${ }^{1}$, \\ Adaan Sudário Dias ${ }^{1}$, Lauriane Almeida dos Anjos Soares ${ }^{2}$, Reginaldo Gomes Nobre ${ }^{4}$, Pedro Dantas \\ Fernandes $^{1}$
}

\author{
${ }^{1}$ Federal University of Campina Grande, Academic Unit of Agricultural Engineering, Campina Grande, 58.109-970, \\ Paraíba, Brazil \\ ${ }^{2}$ Federal University of Campina Grande, Academic Unit of Agrarian Sciences, Pombal, 58.840-000, Paraíba, Brazil \\ ${ }^{3}$ Federal University of Recôncavo of Bahia, Water and Soil Engineering Center, Cruz das Almas, 44.380-000, Bahia, \\ Brazil \\ ${ }^{4}$ Federal Rural University of the Semi-arid Region, Department of Science and Technology, Caraúbas, 59.780-000, \\ Rio Grande do Norte, Brazil
}

*Corresponding author: geovanisoareslima@gmail.com

\section{Abstract}

The water resources in the semi-arid region of Northeast Brazil commonly have high concentrations of salts, compromising the quality of the water used in irrigation. Thus, it is necessary to study the feasibility of using these resources in agriculture. The present study aimed to evaluate gas exchanges, photosynthetic pigments and growth of white cotton cv. BRS 368 RF using irrigation water of different salinity levels and fertilization with combinations of nitrogen and potassium, under greenhouse conditions in the municipality of Campina Grande-PB, Brazil. Treatments were arranged in randomized blocks in a $5 \times 4$ factorial scheme, with five levels of electrical conductivity of water-ECW $\left(0.7,2.2,3.7,5.2\right.$ and $\left.6.7 \mathrm{dS} \mathrm{m}^{-1}\right)$ and four combinations of fertilization with nitrogen and potassium $(70 / 50,100 / 75,130 / 100,160 / 125 \%$ of the recommended dose), with three replicates. There was degradation in chlorophyll $a$ and $b$ levels and in cotton growth, but the cultivar BRS 368 RF markedly increased carotenoid biosynthesis at 75 days after sowing. Nitrogen and potassium application in the combination of 100/75\% of their respective recommendations led to increase in plant height. The supply of nitrogen in combination with potassium did not alleviate the deleterious effects of salt stress on gas exchange, photosynthetic pigments and growth of cotton.

Keywords: Gossypium hirsutum L., salt stress, physiology.

Abbreviations: DAS_days after sowing; ECw_electrical conductivity of water; PH_plant height; SD_stem diameter, NL_number of leaves LA_leaf area; $g s \_s t o m a t a l$ conductance; $A_{-}$assimilation rate, E_transpiration; $\mathrm{Ci}_{-}$internal $\mathrm{CO}_{2}$ concentration; $\mathrm{Chl}$ $a$ _chlorophyll $a$; $C h l b$ _chlorophyll $b$; Car_carotenoids.

\section{Introduction}

Herbaceous cotton (Gossypium hirsutum L.) is one of the main crops exploited in Brazil, especially for the production of fiber, raw material of the Brazilian and global textile industries. Cotton cultivation generates products with various industrial applications, and all plant parts are used. Cotton fruit is composed of seeds (52\%), fibers (40\%) and other botanic structures (8\%) (Brasil, 2007). The ripe capsule, or cotton boll, is harvested and both its seeds and its fibers can be used after ginning. The fiber has greater economic importance, and its main product is the lint, which is used in a series of textile varieties. From the seed, part is used as animal feed without any processing and the remaining portion is crushed in machines to obtain oil, cake and meal (Abrapa, 2013).

Brazil is currently the fifth largest cotton producer, with $6.5 \%$ of the total world production, only behind India, China,
USA and Pakistan. In addition, the country is the third largest exporter, exporting about $50 \%$ of the national production. In the 2016/2017 season, mean seed cotton yield was estimated at $2.38 \mathrm{t} \mathrm{ha}^{-1}$, in a planted area of approximately 938,000 hectares (Conab, 2017).

The area cultivated with cotton in the Northeastern semiarid region is very small, due to the low yield and competitiveness caused by several factors, particularly including disorganization in the regional production chain, occurrence of water deficit and low levels of technology, such as mechanization, increasing the costs with labor, which has currently become scarce and expensive (Embrapa, 2017). In addition, the availability of water for irrigation has been gradually reduced in both quality and quantity, making it necessary to use waters with high concentrations of salts in order to meet the water requirements of crops in this 
region (Silva et al., 2014). For this region, the use of saline waters has stood out as an alternative capable of minimizing water scarcity. High concentrations of salts in water and/or soil are among the main environmental factors limiting the growth and yield of crops, besides reducing the osmotic potential of the soil solution, compromising water absorption, possibly leading to toxic effects on plants, and causing functional disorders and damage in their metabolism (Silva et al., 2009). Although cotton is considered as a salt-tolerant crop, its salinity threshold is 5.1 $\mathrm{dS} \mathrm{m}^{-1}$ in the irrigation water and $7.7 \mathrm{dS} \mathrm{m}^{-1}$ in the soil saturation extract (Ayers and Westcot, 1999), salinity can cause deleterious effects on cultivars of the same species, depending on factors such as type and concentration of salts, intensity and duration of stress, fertilization management and nutritional status of the crop (Munns and Tester, 2008). Some techniques have been developed in an attempt to minimize the deleterious effects of excess salts in water and/or soil on plants. Fertilization management stands out as an important strategy, based on the use of fertilizers, capable of favoring nutrient acquisition by plants under saline conditions (Silva et al., 2011). According to Wei et al. (2018), fertilization is one of the main technologies used to increase crop yield and profitability, and nitrogen is one of the main responsible for such increment because this macronutrient is a component of several molecules which are important for plant metabolism, such as amino acids, proteins, enzymes, RNA, DNA, ATP and chlorophyll.

Potassium participates in several stages of the metabolism, such as the reaction of phosphorylation, synthesis of carbohydrates, proteins, respiration and regulation of stomatal opening and closure. It is important in root development and essential in fruit production and maturation, because it is responsible for converting starch into sugars (Taiz et al., 2017). According to Venkajesan et al. (2004), there is a positive correlation between the activity of the nitrate reductase enzyme and potassium fertilization. According to Matsumoto et al. (2013), combined nitrogen and potassium fertilizations contribute to the increase of leaf nutrient ratios, reducing $\mathrm{Cl}^{-} / \mathrm{NO}_{3}{ }^{-}$and $\mathrm{Na}^{+} / \mathrm{K}^{+}$ratios, restoring nutritional equilibrium and mitigating the toxic effects of $\mathrm{Na}^{+}$and $\mathrm{Cl}^{-}$ions on the plant, consequently promoting an increase in crop tolerance. Gurgel et al. (2010) showed that potassium fertilization reduced the deleterious effects of high-salinity water on the melon cv. 'Goldex'. In this context, this study aimed to evaluate gas exchanges, photosynthetic pigments and growth of white cotton cv. BRS $368 \mathrm{RF}$ as a function of irrigation with saline water and different combinations of fertilization with nitrogen and potassium, at 45 and 75 days after sowing.

\section{Results and Discussion}

\section{Effect of salt stress and nitrogen and potassium fertilization on cotton fiber growth}

There was no significant $(p>0.05)$ effect (Table 1$)$ of the interaction between salinity levels and combinations of $N$ and $\mathrm{K}(\mathrm{SL} \times \mathrm{NK})$, on the variables analyzed. Considering the factors separately, water salinity levels had significant $(p<0.01)$ effect on plant height $(P H)$, stem diameter $(S D)$, number of leaves (NL) and leaf area (LA) of cotton in both periods of evaluation. On the other hand, the combinations of fertilization with $\mathrm{N}$ and $\mathrm{K}$ (NK) had significant influence on plant height $(p<0.01)$ at 75 DAS. According to the regression equations obtained for plant height (Fig 1A), this variable decreased linearly as the levels of irrigation water salinity increased, with reductions of 8.12 and $10.09 \%$ per unit increase in ECW at 45 and 75 DAS, respectively. Lower deleterious effect of irrigation water salinity on $\mathrm{PH}$ was observed at 45 DAS, whereas at 75 DAS the stress on the crop was intensified and there was greater reduction compared with the first evaluation. Thus, it is possible to note the sensitivity of this crop as a sign of the negative effect caused by the salt stress on the plants. Salinity affects water absorption and growth of plants due to the decrease in the water potential of the soil solution through the osmotic effect of $\mathrm{Na}^{+}$and $\mathrm{Cl}^{-}$salts (Jouyban, 2012). Thus, the reduction in the $\mathrm{PH}$ of the cotton $\mathrm{Cv}$. BRS $368 \mathrm{RF}$, due to the increase in $\mathrm{ECW}$, is probably related to the lower absorption of water caused by the decrease in the osmotic potential of the soil solution (Oliveira et al., 2012). The height of cotton plants CV. BRS 368 RF (Fig 1B) at 75 DAS was significantly different according to the different combinations of $\mathrm{N}$ and $\mathrm{K}$. Based on the means comparison test (Fig 1B), it can be observed that plants receiving $100 / 75 \%$ of $\mathrm{N}$ and $\mathrm{K}$ showed the greatest PH $(59.73 \mathrm{~cm})$, and the lowest value $(51.14 \mathrm{~cm})$ was observed in plants subjected to the treatment with $160 / 125 \%$ of the recommendation for $\mathrm{N}$ and $\mathrm{K}$. On the other hand, plants subjected to fertilization with $75 / 50,100 / 75$ and $130 / 100 \%$ of $\mathrm{N}$ and $\mathrm{K}$ did not differ. The reduction in cotton height is possibly related to the competitive inhibition of the ions, because this nutrient is frequently absorbed by many species in quantities greater than those required, and under these conditions the excess of $K$ may interfere with the absorption of other cations by crops, especially when they compete for the same absorption sites in root tissues, inhibiting the absorption of $\mathrm{Ca}^{2+}$ and $\mathrm{Mg}^{2+}$ (Meurer, 2006). Stem diameter was also negatively and linearly affected by the increment in the levels of irrigation water salinity and, based on the estimates of the regression equations (Fig 2A), there were reductions of 0.348 and 0.547 $\mathrm{mm}$ per unit increase in irrigation water electrical conductivity, at 45 and 75 DAS. Plants grown under the highest water salinity level $\left(6.7 \mathrm{dS} \mathrm{m}^{-1}\right)$ showed reductions of 35.72 and $44.67 \%$, respectively, compared with those irrigated with $0.7 \mathrm{dS} \mathrm{m}^{-1}$ water. According to Taiz et al. (2017), physiological processes are affected by water stress because, under conditions of lower water availability, cell turgor is decreased, leading to a reduced rate of cell expansion and division, which compromises plant growth in height and stem diameter. Lima et al. (2017), studying the impacts of different levels of irrigation water salinity (5.1 to $9.1 \mathrm{dS} \mathrm{m}^{-1}$ ) on the colored cotton 'BRS Rubi', also found significant effects of ECW on stem diameter, with reductions of $1.83 \mathrm{~mm}(22.34 \%)$ per unit increase in $\mathrm{ECW}$ at 83 days after sowing. As observed for SD (Fig 2A), the number of leaves (Fig 2B) also decreased due to the increase in irrigation water salinity, with reductions of 10.18 and $13.49 \%$ per unit increase in ECW, which corresponded to decreases of 13.33 and 37.46 leaves in cotton plants irrigated with $6.7 \mathrm{dS} \mathrm{m}^{-1}$ water in comparison to those subjected to the lowest salinity level $\left(0.7 \mathrm{dS} \mathrm{m}^{-1}\right)$, at 45 and 75 DAS respectively. The reduction in the number of leaves under high-salinity conditions $\left(6.7 \mathrm{dS} \mathrm{m}^{-1}\right)$ is probably related to the action of the osmotic component, besides the 
possibility of occurrence of ionic toxicity, which makes it difficult for water to enter plant cells (Ambede et al., 2012), resulting in alterations in the photosynthetic capacity, consequently inhibiting plant growth. In addition, the reduction in the number of leaves can be considered as an adaptive mechanism of the plant because, under salt stress conditions, morphological and anatomical alterations are common, which lead to reduction of transpiration as an alternative to maintain low absorption of toxic ions, especially $\mathrm{Na}^{+}$and $\mathrm{Cl}^{-}$(Bezerra et al., 2018).

The leaf area of cotton cV. BRS 368 RF was also negatively influenced by irrigation water salinity, and a decreasing linear model fitted best to the data for both periods of evaluation (45 and 75 DAS). The reductions in leaf area were equal to 12.81 and $14.28 \%$ per unit increase in $E C w$ and corresponded to 268.75 and $603.36 \mathrm{~cm}^{2}$ per unit increase in $\mathrm{ECW}$ at 45 and $75 \mathrm{DAS}$, respectively (Fig $2 \mathrm{C}$ ). Leaf area is one of the growth variables most affected by salinity because, under salt stress, the photosynthetic apparatus contributes to the decline in the capacity of production of organic assimilates and results in the inhibition of plant growth, leading to reductions in transpiration and net $\mathrm{CO}_{2}$ assimilation rate, caused by stomatal closure in response to the low water potential in the soil, due to the high concentration of salts. The reduction in leaf area represents a mechanism of defense of plants under water and salt stress conditions, reducing water losses through transpiration (Bezerra et al., 2018). According to Gratão et al. (2005), leaves are more vulnerable to $\mathrm{Na}^{+}$and $\mathrm{Cl}^{-}$than roots and stem simply because they accumulate higher concentrations of these ions, which results in reduction in cell expansion, causing a decrease in plant growth, since both are transported through the transpiration stream in the xylem and accumulate in the leaves when water is transpired.

\section{Effect of salt stress and nitrogen and potassium fertilization on the photosynthetic pigments of white cotton}

Based on the summary of analysis of variance (Table 2), the interaction between factors (SL $\times \mathrm{NK}$ ) had no significant $(p>0.05)$ influence on any of the variables evaluated. Separately, only water salinity levels caused significant $(\mathrm{p}<0.01)$ effect on the contents of chlorophyll $a(\mathrm{Chl} a), b$ $(\mathrm{Ch} / \mathrm{b})$, and carotenoids (Car).

The increment in water salinity levels led to reduction in chlorophyll $a$ content (Fig 3A), $11.73 \%$ per unit increase in ECW, which corresponded to a decrease of $76.69 \%$ in $\mathrm{Chl} \mathrm{a}$ content in the leaves of plants irrigated with water of highest salinity $\left(6.7 \mathrm{dS} \mathrm{m}^{-1}\right)$ compared with those under ECW of $0.7 \mathrm{dS} \mathrm{m}^{-1}$. Reduction in chlorophyll $a$ synthesis, due to salt stress, cannot be interpreted only as a consequence of the deleterious effects of salts on plant metabolism, because the decrease in chlorophyll $a$ contents can be a response of acclimation to the action of stressing agents, adopted by some plants in the attempt to save energy and, therefore, capture less light energy, thus avoiding possible photooxidative stress (Tabot et al., 2013).

For the content of chlorophyll $b$, the regression equation (Fig 3B) revealed a negative linear effect as a function of the increase in ECW, and the reduction was approximately $11.75 \%$ per unit increase in $\mathrm{ECW}$, i.e., plants subjected to irrigation with $6.7 \mathrm{dS} \mathrm{m}^{-1}$ water showed reduction of $76.84 \%$ in $\mathrm{Chl} b$ content, compared with those irrigated with $0.7 \mathrm{dS}$ $\mathrm{m}^{-1}$. Reduction in $\mathrm{Chl} b$ content in cotton plants subjected to salt stress may have occurred because of the increase in the synthesis of the enzyme chlorophyllase, which acts on the degradation of the molecules of this photosynthesizing pigment (Campos et al., 2012).

The content of carotenoids (Car) in the cotton cv. BRS 368 RF increased linearly as a function of irrigation with increasing levels of salinity and, according to the regression equation (Fig 3C), it increased by $27.80 \%$ per unit increase in electrical conductivity. The contents of carotenoids decreased by $58.26 \%$ in plants irrigated with $6.7 \mathrm{dS} \mathrm{m}^{-1}$ water, compared with those subjected to the lowest level of water salinity (0.7 $\mathrm{dS} \mathrm{m}^{-1}$ ). Such situation is extremely important for crops under saline conditions, because carotenoids act in the control of free radicals produced in greater quantity when the plant is under stress. Sayyad-Amin et al. (2016) mention that under such conditions there is an increase in carotenoid contents and reduction in chlorophyll biosynthesis, which causes lower absorption of energy by leaves and, therefore, an increase in visible reflectance, characterized by the yellow or chlorotic color in the plants.

\section{Effect of salt stress and nitrogen and potassium fertilization on the gas exchanges of white cotton}

There was no significant $(p>0.05)$ effect of the interaction between salinity levels and combinations of $N$ and $K$ (SL $x$ $\mathrm{NK}$ ) on the gas exchange variables analyzed (Table 3 ). Considering the factors separately, fertilization with NK caused no significant $(p>0.05)$ effect, but water salinity levels significantly $(p<0.01)$ affected stomatal conductance $(g s)$, transpiration $(E), \mathrm{CO}_{2}$ assimilation rate $(A)$, internal $\mathrm{CO}_{2}$ concentration $(\mathrm{C} i)$, instantaneous water use efficiency (WUEi) and instantaneous carboxylation efficiency (EiCi) in cotton plants cv. BRS $368 \mathrm{RF}$, at 75 days after sowing.

Increase in the electrical conductivity of irrigation water caused linear decreases in stomatal conductance ( $g s$ ) (Fig $4 \mathrm{~A}$ ), of the order of $10.44 \%$ per unit increase in ECW. There was a decrease of $67.63 \%$ in the $g s$ of plants subjected to the highest salinity level $\left(6.7 \mathrm{dS} \mathrm{m}^{-1}\right)$, compared with those under the lowest concentration of salts $\left(0.7 \mathrm{dS} \mathrm{m}^{-1}\right)$. According to Sousa et al. (2018), the reduction in stomatal conductance occurs because plants under salt stress close their stomata to reduce water loss by transpiration, resulting in a lower photosynthetic rate, due to reduced partial pressure of $\mathrm{CO}_{2}$ in the intercellular spaces or in the substomatal chamber, which is one of the causes for the reduced growth of species cultivated under high-salinity conditions.

The transpiration of the cotton cV. BRS 368 RF was negatively affected by irrigation water salinity and, according to the regression equation (Fig 4B), there was a reduction of $0.2173 \mathrm{mmol} \mathrm{H}_{2} \mathrm{O} \mathrm{m}^{-2} \mathrm{~s}^{-1}$ per unit increase in $\mathrm{ECW}$. In addition, when plants were irrigated using water of highest salinity level $\left(6.7 \mathrm{dS} \mathrm{m}^{-1}\right)$, transpiration decreased by $56.24 \%$ in comparison to plants under ECw of $0.7 \mathrm{dS} \mathrm{m}^{-1}$. Furthermore, reduction in $E$ can be attributed to the partial closure of the stomata, as a strategy of the plants to avoid excessive dehydration of guard cells, or to water imbalance, a mechanism which leads to reduction in $\mathrm{CO}_{2}$ diffusion and, consequently, reduction in $\mathrm{CO}_{2}$ assimilation rate (Time et al., 2018). According to Gonçalves et al. (2010), a close relation 
Table 1. Summary of analysis of variance for plant height (PH), stem diameter (SD), number of leaves (NL) and leaf area (LA) of white cotton cv. BRS 368 RF irrigated with saline waters and fertilized with different combinations of nitrogen and potassium, at 45 and 75 days after sowing (DAS).

\begin{tabular}{|c|c|c|c|c|c|c|c|c|}
\hline \multirow{4}{*}{ Source of variation } & \multicolumn{8}{|c|}{ Mean squares } \\
\hline & $\mathrm{PH}$ & & SD & & $\mathrm{NL}$ & & LA & \\
\hline & \multicolumn{8}{|c|}{ Days after sowing } \\
\hline & 45 & 75 & 45 & 75 & 45 & 75 & 45 & 75 \\
\hline Saline levels (SL) & $1386.43^{n}$ & 5585.96 & $9.55^{* *}$ & $22.57^{*}$ & 399.51 & 2929.91 & $5904739.15^{* \prime \prime}$ & $27226269.55^{*}$ \\
\hline Nitrogen/Potassium (NK) & $57.91^{\mathrm{ns}}$ & $190.19^{* *}$ & $0.35^{\mathrm{ns}}$ & $0.23^{\text {ns }}$ & $16.17^{\text {ns }}$ & $80.02^{\mathrm{ns}}$ & $75074.29^{\text {ns }}$ & $441401.01^{\mathrm{ns}}$ \\
\hline Interaction (SL x NK) & $14.63^{\text {ns }}$ & $27.53^{\text {ns }}$ & $0.30^{\mathrm{ns}}$ & $0.38^{\text {ns }}$ & $4.42^{\text {ns }}$ & $26.16^{\text {ns }}$ & $95532.46^{\text {ns }}$ & $871718.59^{\text {ns }}$ \\
\hline Blocks & $156.21^{\mathrm{ns}}$ & $173.37^{\mathrm{ns}}$ & $0.05^{\mathrm{ns}}$ & $0.60^{\mathrm{ns}}$ & $36.15^{\mathrm{ns}}$ & $6.81^{\text {ns }}$ & $732308.43^{\text {ns }}$ & $961657.01^{\mathrm{ns}}$ \\
\hline Residual & 33.69 & 34.75 & 0.40 & 0.42 & 11.06 & 39.71 & 109684.07 & 1117223.90 \\
\hline CV (\%) & 15.38 & 10.73 & 13.17 & 11.45 & 24.46 & 27.20 & 30.03 & 53.0 \\
\hline
\end{tabular}
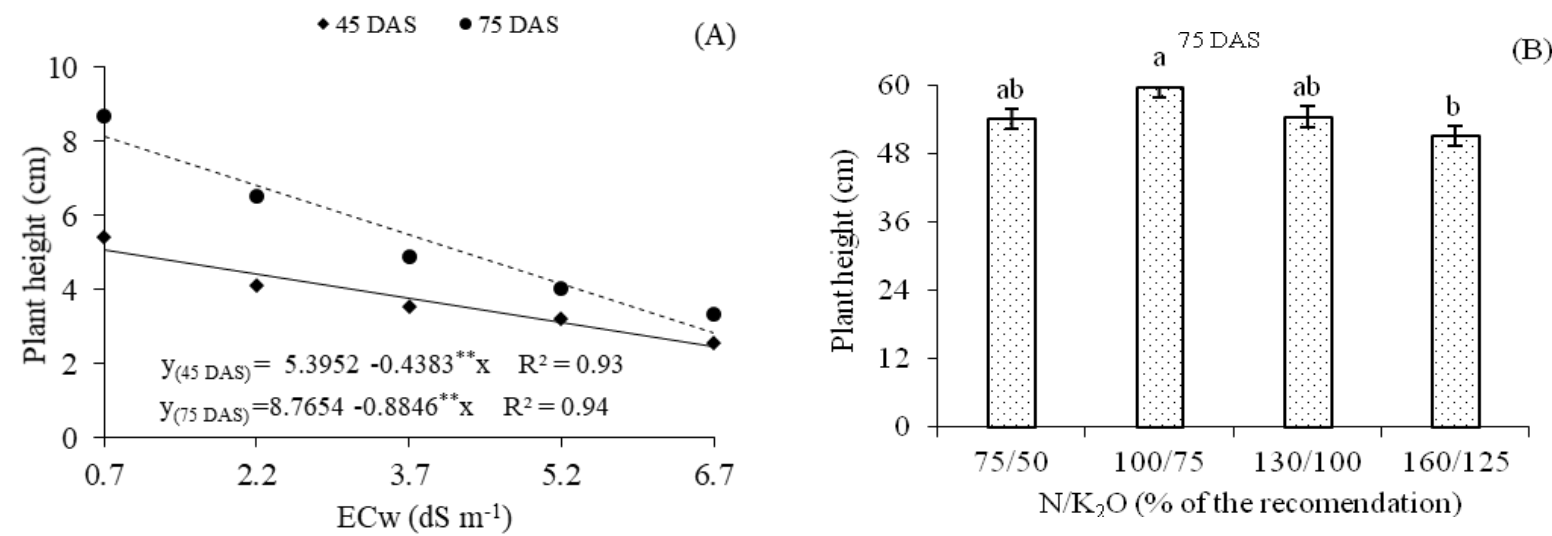

Fig 1. Plant height of white cotton cv. BRS 368 RF as a function of irrigation water salinity - ECW (A), at 45 and 75 days after sowing (DAS), and of the combination of fertilization with nitrogen and potassium (B), at 75 DAS. Means followed by the same letter do not differ by Tukey test $(p<0.05)$; Bars represent standard error of the mean $(n=3)$.

Table 2. Summary of analysis of variance for the contents of chlorophyll $a(\mathrm{Chl} a), b(\mathrm{Chl} b)$, and carotenoids (Car) in white fiber cotton cV. BRS 368 RF irrigated with waters of different salinity levels and combinations of fertilization with nitrogen and potassium, at 75 days after sowing.

\begin{tabular}{llll}
\hline \multirow{2}{*}{ Source of variation } & \multicolumn{3}{c}{ Mean squares } \\
\cline { 2 - 4 } & Chla & $C h / b$ & Car \\
\hline Saline levels (SL) & $48.1175^{* *}$ & $9.7026^{* *}$ & $3.0340^{* *}$ \\
Nitrogen/Potassium (NK) & $1.0904^{\text {ns }}$ & $0.1895^{\text {ns }}$ & $2.2819^{\text {ns }}$ \\
Interaction (SL x NK) & $2.7228^{\text {ns }}$ & $1.7051^{\text {ns }}$ & $0.5054^{\text {ns }}$ \\
Blocks & $0.6465^{\text {ns }}$ & $2.7251^{\text {ns }}$ & $0.2374^{\text {ns }}$ \\
Residual & 2.2315 & $1.0538^{\text {ns }}$ & $0.9428^{\text {ns }}$ \\
\hline CV (\%) & 18.07 & 16.14 & 12.63 \\
ns, ${ }^{* *},{ }^{*}$ respectively, not significant, significant at $\mathrm{p}<0.01$ and $\mathrm{p}<0.05$. & &
\end{tabular}

Table 3. Summary of analysis variance for stomatal conductance $(g s)$, transpiration $(E), \mathrm{CO}_{2}$ assimilation rate $(A)$, internal $\mathrm{CO}_{2}$ concentration $(\mathrm{Ci})$, instantaneous water use efficiency (WUEi) and instantaneous carboxylation efficiency (EiCi) of white cotton plants cv. BRS 368 RF irrigated with waters of different salinity levels and combinations of fertilization with nitrogen and potassium, at 75 days after sowing.

\begin{tabular}{lllllll}
\hline \multirow{2}{*}{ Source of variation } & \multicolumn{5}{c}{ Mean squares } \\
\cline { 2 - 7 } & gs & $E$ & $A$ & $C i$ & WUEi & EiCi \\
\hline Saline levels (SL) & $0.0120^{* *}$ & $3.18^{* *}$ & $164.35^{* *}$ & $14545.49^{* *}$ & $12.82^{* *}$ & $0.0076^{* *}$ \\
Nitrogen/Potassium (NK) & $0.0009^{\text {ns }}$ & $0.23^{\text {ns }}$ & $8.58^{\text {ns }}$ & $2412.26^{\text {ns }}$ & $2.89^{\text {ns }}$ & $0.0003^{\text {ns }}$ \\
Interaction (SL x NK) & $0.0004^{\text {ns }}$ & $0.09^{\text {ns }}$ & $2.84^{\text {ns }}$ & $2390.03^{\text {ns }}$ & $2.14^{\text {ns }}$ & $0.0004^{\text {ns }}$ \\
Blocks & $0.0009^{\text {ns }}$ & $1.68^{\text {ns }}$ & $11.04^{\text {ns }}$ & $385.66^{\text {ns }}$ & $7.09^{\text {ns }}$ & $0.0005^{\text {ns }}$ \\
Residual & $0.0004^{\text {ns }}$ & $0.13^{\text {ns }}$ & $4.37^{\text {ns }}$ & $1925.60^{\text {ns }}$ & $2.60^{\text {ns }}$ & $0.0002^{\text {ns }}$ \\
\hline CV (\%) & 26.44 & 21.71 & 26.83 & 20.78 & 34.95 & 38.77 \\
\hline
\end{tabular}




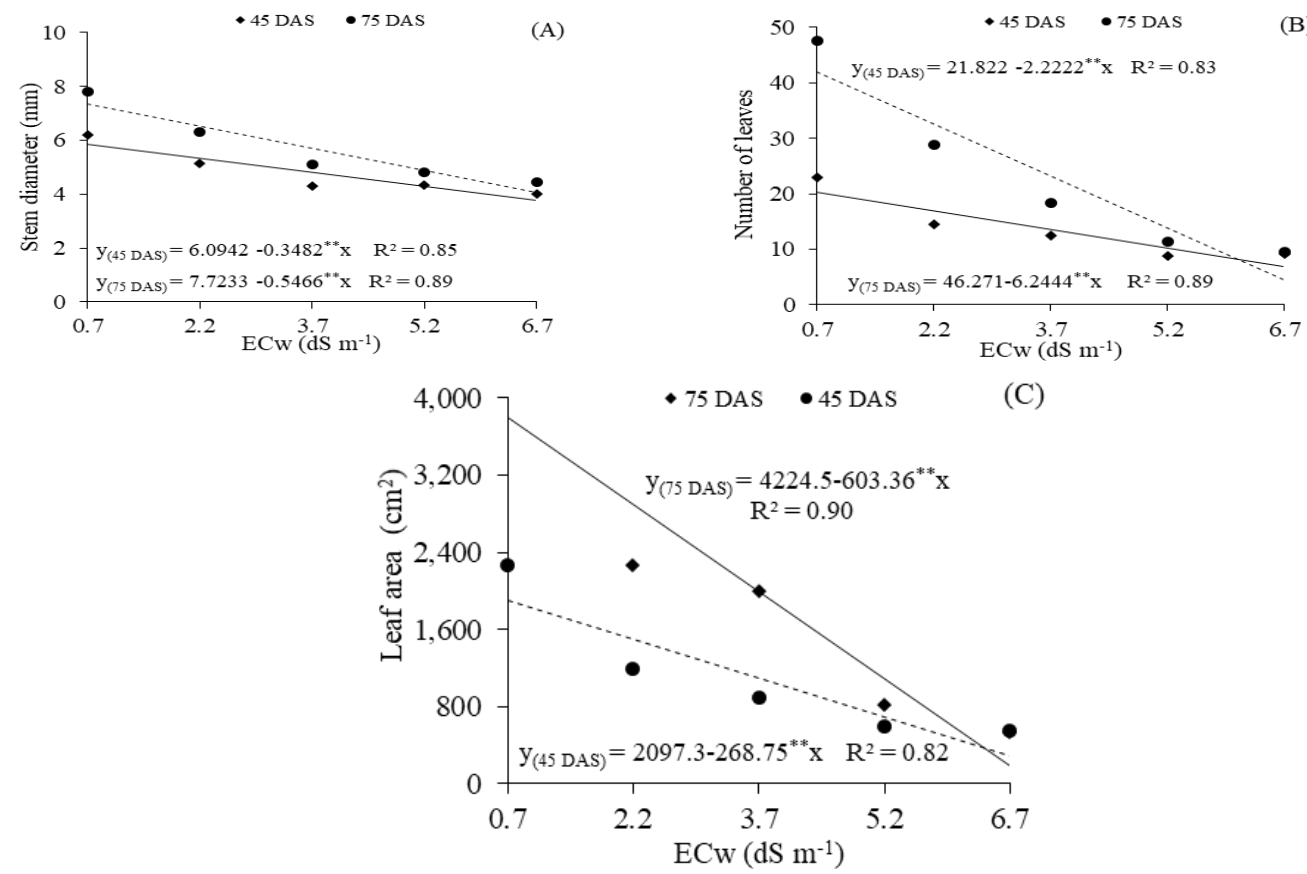

Fig 2. Stem diameter (A), number of leaves (B) and leaf area (C) of white cotton cv. BRS 368 RF, as a function of irrigation water salinity $-E C W$, at 45 and 75 days after sowing (DAS).
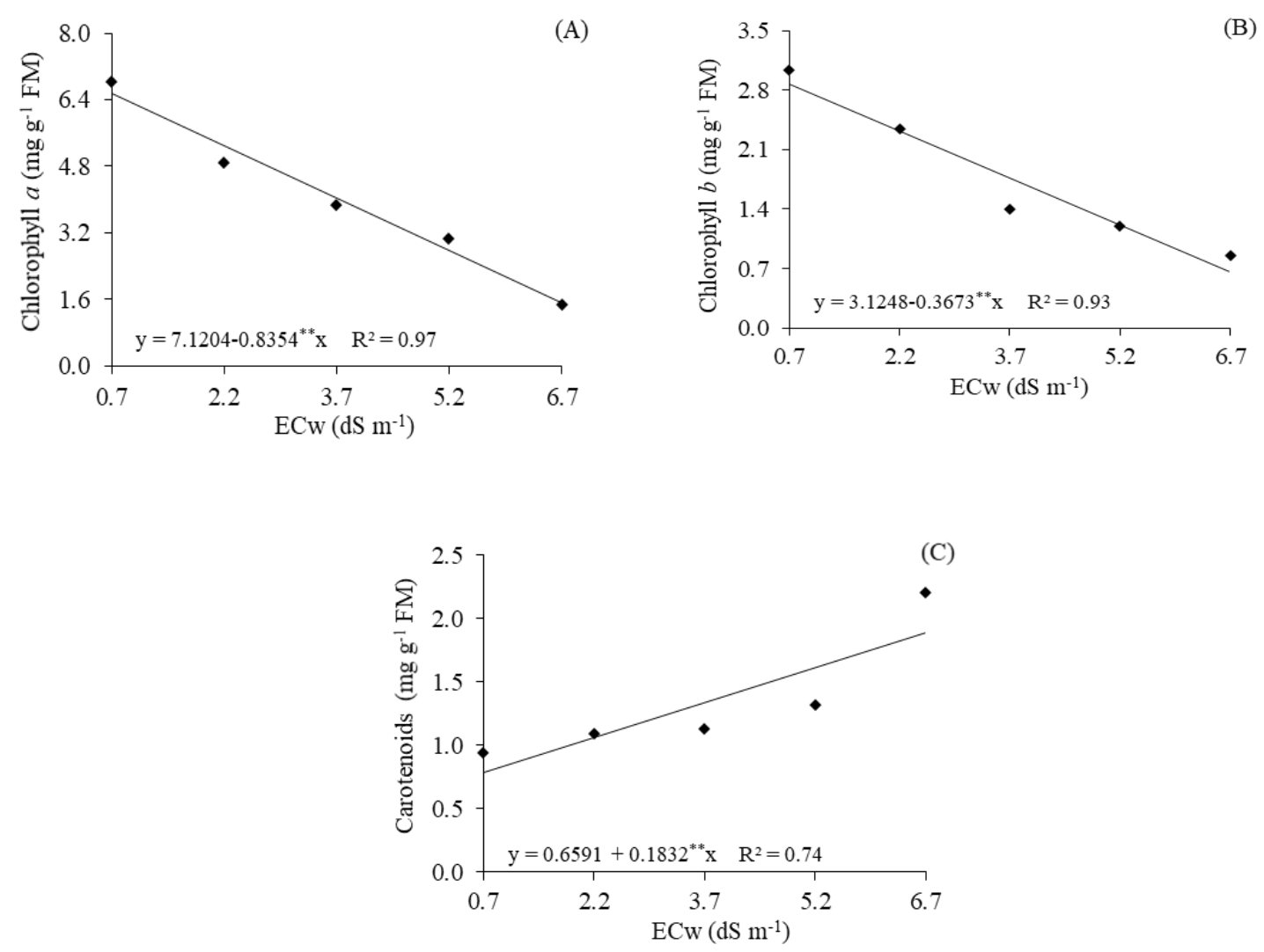

Fig 3. Contents of chlorophyll $a(\mathrm{~A})$, chlorophyll $b(\mathrm{~B})$ and carotenoids (C) in white cotton $\mathrm{cv}$. BRS $368 \mathrm{RF}$, as a function of irrigation water salinity - ECW, at 75 days after sowing. 

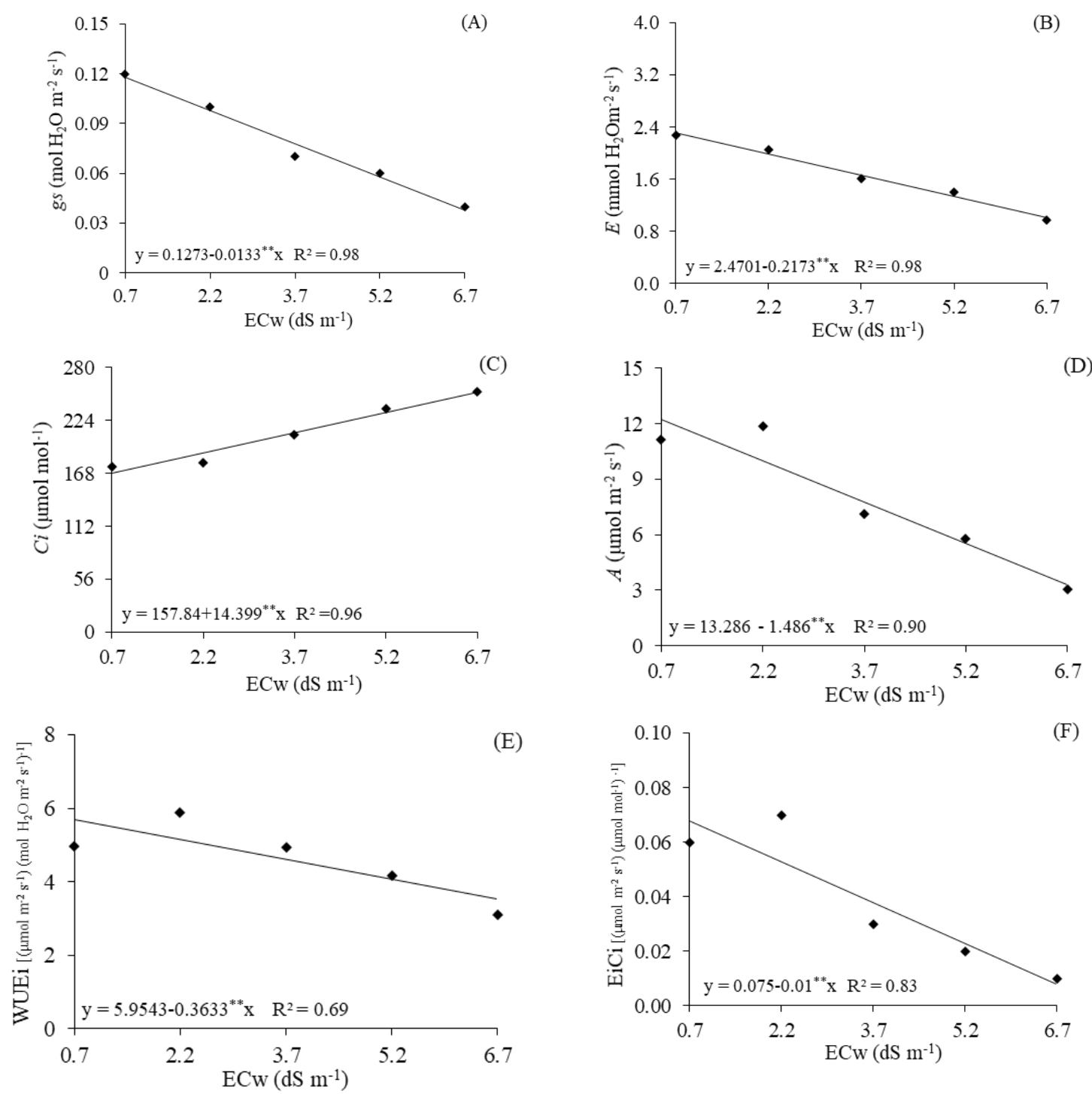

Fig 4. Stomatal conductance - gs (A), transpiration $-E(B)$, internal $\mathrm{CO}_{2}$ concentration $-\mathrm{Ci}(\mathrm{C}), \mathrm{CO}_{2}$ assimilation rate $-A(D)$, instantaneous water use efficiency - WUEi (E) and instantaneous carboxylation efficiency - EiCi (F) of white cotton cv. BRS 368 RF, as a function of irrigation water salinity - ECW, at 75 days after sowing.

between $g s$ and $E$ is expected because of the decrease in water vapor flux to the atmosphere, and therefore in transpiration, as the stomata close. The internal $\mathrm{CO}_{2}$ concentration of cotton cV. BRS 368 RF increased linearly as the levels of irrigation water salinity increased. According to the regression equation (Fig $4 \mathrm{C}$ ), it was equal to $254.31 \mu \mathrm{mol}$ $\mathrm{mol}^{-1}$ in plants irrigated with $6.7 \mathrm{dS} \mathrm{m}^{-1}$ and to $167.92 \mu \mathrm{mol}$ $\mathrm{mol}^{-1}$ in plants subjected to the lowest salinity level $(0.7 \mathrm{dS}$ $\mathrm{m}^{-1}$ ). In other words, irrigation using water with high conductivity led to increment of $51.45 \%$ in the $\mathrm{Ci}$ of cotton plants cv. BRS $368 \mathrm{RF}$. The increase in $\mathrm{Ci}$ is related to the low values of leaf water potential, resulting in the reduction of gs (Fig 4A), caused by the decline in the osmotic potential of the solution, in addition to the reduction in the activity of enzymes involved in $\mathrm{CO}_{2}$ fixation. Under salt stress conditions, the increase of $\mathrm{CO}_{2}$ in the substomatal chamber indicates that it is not being used for the synthesis of sugars during the photosynthetic process, which leads to accumulation of this gas, suggesting the interference of a non-stomatal factor in this process, which may result in damage to the photosynthetic apparatus of the plants (Morais et al., 2018). Contrary to what was observed for $C i$ (Fig $4 \mathrm{C}$ ), the $\mathrm{CO}_{2}$ assimilation rate (Fig $4 \mathrm{~B}$ ) of cotton plants CV. BRS 368 RF decreased linearly as irrigation water salinity increased. According to the regression equation (Fig 4B), there was a reduction in $\mathrm{CO}_{2}$ assimilation rate of $11.18 \%$ per unit increase in $\mathrm{ECW}$, which is equivalent to a decline of $90.74 \%$ in the $A$ of cotton plants irrigated with $6.7 \mathrm{dS} \mathrm{m}^{-1}$ in comparison with those subjected to ECW of $0.7 \mathrm{dS} \mathrm{m}^{-1}$. The reduction in $\mathrm{CO}_{2}$ assimilation rate in response to the increase in irrigation water salinity may have occurred due to the osmotic effect associated with the accumulation of soluble salts in the soil and the decrease in root hydraulic conductivity caused by the increase in suberization and lignification of the vascular tissues of the roots of plants under salt stress conditions (Lima et al., 2014). The 
instantaneous water use efficiency (WUEi) decreased linearly with the increase in irrigation water salinity, by $6.10 \%$ per unit increase in $\mathrm{ECW}$, i.e., plants irrigated with of $6.7 \mathrm{dS} \mathrm{m}^{-1}$ water had a $38.24 \%$ decrease in comparison to those subjected to ECW of $0.7 \mathrm{dS} \mathrm{m}^{-1}$ (Fig 4E). As observed in the case of the instantaneous water use efficiency (WUEi), the instantaneous carboxylation efficiency (EiCi) also decreased linearly with the increase in irrigation water salinity, by $13.33 \%$ per unit increase in ECw, i.e., plants irrigated with $6.7 \mathrm{dS} \mathrm{m}^{-1}$ showed reduction of $88.23 \%$ in comparison to those subjected to ECW of $0.7 \mathrm{dS} \mathrm{m}^{-1}$ (Fig 4F). Such result is probably a consequence of greater $\mathrm{CO}_{2}$ assimilation compared with the $\mathrm{CO}_{2}$ found in the substomatal chamber because, if $\mathrm{Ci}$ increases due to the rate of stomatal opening, the entry of $\mathrm{CO}_{2}$ in the leaf mesophyll may have decreased because of the reduction in $g s$, but $\mathrm{CO}_{2}$ consumption in the chloroplast may have been reduced as well (Ouyang et al., 2017). According to Soares et al. (2018), osmotic stress, associated with accumulation of salts in the soil, reduces water availability to plants and, therefore, can affect their gas exchanges and growth.

\section{Materials and methods}

\section{Plant material}

The cotton cultivar used in the experiment was BRS $368 \mathrm{RF}$, which is a transgenic material, resistant to the herbicide glyphosate, with fiber yield of $40 \%$ and production potential between 4,200 and $4,500 \mathrm{~kg} \mathrm{ha}^{-1}$. It is a dwarf cultivar, with cycle from medium to early, first flower opening at 55 days and crop cycle between 165 and 170 days (Embrapa, 2017).

\section{Localization, experimental procedure, treatments}

The study was carried out under greenhouse conditions at the Center of Technology and Natural Resources of the Federal University of Campina Grande (CTRN/UFCG), located in the municipality of Campina Grande, PB, situated at local geographic coordinates $7^{\circ} 15^{\prime} 18^{\prime \prime} \mathrm{S}, 35^{\circ} 52^{\prime} 28^{\prime \prime} \mathrm{W}$ and altitude of $550 \mathrm{~m}$. The experimental design was in randomized blocks, with three replicates, using a $5 \times 4$ factorial scheme, and treatments consisted of five levels of irrigation water electrical conductivity - ECW $(0.7,2.2,3.7$, 5.2 and $6.7 \mathrm{dS} \mathrm{m}^{-1}$ ) and four combinations of fertilization with nitrogen and potassium - NK (70:50, 100:75, 130:100, $160: 125 \%$ of the respective recommendation). The dose relative to $100 \%$, as recommended by Novais et al. (1991) for pot experiments, corresponded to $100 \mathrm{mg} \mathrm{kg}^{-1}$ of $\mathrm{N}$ and $150 \mathrm{mg} \mathrm{kg}^{-1}$ of $\mathrm{K}_{2} \mathrm{O}$.

Saline waters were prepared by dissolving the salts $\mathrm{NaCl}$, $\mathrm{CaCl}_{2} \cdot 2 \mathrm{H}_{2} \mathrm{O}$ and $\mathrm{MgCl}_{2} \cdot 6 \mathrm{H}_{2} \mathrm{O}$, at equivalent proportion of $7: 2: 1$, respectively, in water $\left(E C W=0.6 \mathrm{dS} \mathrm{m}^{-1}\right)$ from the public supply system of Campina Grande-PB, and their quantities were determined based on the relationship between ECW and the concentration of salts $\left(10^{*} \mathrm{mmol}_{\mathrm{C}} \mathrm{L}^{-1}=\right.$ ECW dS $\mathrm{m}^{-1}$ ) according to Richards (1954).

\section{Establishment and management of the experiment}

Drainage lysimeters with capacity for $20 \mathrm{~L}$ were used to grow cotton plants. At the bottom of each lysimeter, a drain was installed using a 4-mm-diameter tube to drain the leachate to a container to evaluate the drained water and determine water consumption of plants. The tip of the drain inside the lysimeter was envolved in a nonwoven geotextile (Bidim OP 30) to avoid clogging by soil material.

The lysimeters were filled with a $0.5-\mathrm{kg}$ layer of crushed stone (No. 0), followed by $25 \mathrm{~kg}$ of a eutrophic Regolithic Neosol with sandy loam texture collected in the $0-20 \mathrm{~cm}$ layer, in the rural area of the municipality of Lagoa Seca, PB. This material was properly pounded to break up clods and sieved, and its physical and chemical characteristics were determined according to the methodologies proposed by Donagema et al. (2011): exchangeable $\mathrm{Ca}^{2+}, \mathrm{Mg}^{2+}, \mathrm{Na}^{+}, \mathrm{K}^{+}$ $\mathrm{Al}^{3+}+\mathrm{H}^{+}=2.60,3.66,0.16,0.22$ and $1.93 \mathrm{cmol}_{\mathrm{c}} \mathrm{kg}^{-1}$, respectively; $\mathrm{pH}$ (soil:water 1:2.5) =5.9; ECse $\left(\mathrm{dS} \mathrm{m}^{-1}\right)=1.0$; organic matter $(\%)=1.36$; sand, silt and clay $=732.9,142.1$, and $125.0 \mathrm{~g} \mathrm{~kg}^{-1}$, respectively; apparent density $\left(\mathrm{kg} \mathrm{dm}^{-3}\right)=$ 1.39; moisture content at 33.42 and $1519.5 \mathrm{kPa}=11.98$ and $4.32 \mathrm{dag} \mathrm{kg}^{-1}$, respectively.

Before sowing, the soil in all lysimeters was brought to field capacity using the respective waters of each treatment. After sowing, irrigation was performed every day, applying in each lysimeter a volume of water sufficient to maintain the soil close to field capacity. The applied volume was determined according to the water requirement of the plants, estimated by water balance: volume applied minus volume drained in the previous irrigation.

Fertilization with phosphorus was carried out as recommended by Novais et al. (1991), using $300 \mathrm{mg}$ of $\mathrm{P}_{2} \mathrm{O}_{5}$ per $\mathrm{kg}$ of soil before planting. Nitrogen and potassium were applied according to the treatments, as top-dressing, in five applications by fertigation at 15-day intervals, with the first one at 10 DAS. Monoammonium phosphate, urea and potassium chloride were used as sources of $\mathrm{P}, \mathrm{N}$ and $\mathrm{K}$, respectively.

Micronutrients were applied at 20, 40 and 60 days, using 4.0 $\mathrm{L}$ of a solution $\left(1.0 \mathrm{~g} \mathrm{~L}^{-1}\right)$ of Ubyfol $\left(\mathrm{N}-15 \% ; \mathrm{P}_{2} \mathrm{O}_{5}-15 \% ; \mathrm{K}_{2} \mathrm{O}-\right.$ 15\%; Ca-1\%; Mg-1.4\%; S-2.7\%; Zn-0.5\%; B- 0.05\%; Fe-(0.5\%; $\mathrm{Mn}-0.05 \%$; Cu-0.5\%; Mo-0.02\%) sprayed on cotton leaves until full wetting of the adaxial and abaxial faces.

\section{Traits measured}

The growth of 'BRS $368 \mathrm{RF}^{\prime}$ cotton was evaluated at 45 and 75 days after sowing (DAS) based on plant height (PH), stem diameter (SD), number of leaves (NL) and leaf area (LA). PH was considered as the distance between collar and apical meristem. SD was measured at $2 \mathrm{~cm}$ from plant collar, whereas NL was obtained by counting the leaves of each plant. LA was obtained by measuring the midrib length of all leaves, following the methodology described by Grimes et al. (1969), according to Eq 1: $y=0.26622 x^{2.3002}$

Where: $y$ is leaf area per leaf, and $x$ is the midrib length of the cotton leaf. Leaf area per plant was determined by the sum of the area of all leaves.

At 75 DAS the contents of chlorophyll $a(C h l a), b(C h l b)$ and carotenoids (Car) were determined following the laboratory method developed by Arnon (1949), in samples of 5 leaf discs from the lamina of the third mature leaf from the apex of the quaternary branch. Their extracts in $80 \%$ acetone were used to determine the contents of chlorophyll and carotenoids in the solution with a spectrophotometer at the 
absorbance wavelength (ABS) $(470,646$, and $663 \mathrm{~nm})$, through the equations: Chlorophyll $a(\mathrm{Ch} / a)=12.21 \mathrm{ABS} 663$ - 2.81 ABS646; Chlorophyll $b(C h l b)=20.13$ ABS646 - 5.03 ABS663; Total carotenoids $(\mathrm{Car})=(1000 \mathrm{ABS} 470-1.82 \mathrm{Chl} a$ $-85.02 \mathrm{Chl} b$ )/198. The obtained contents of chlorophyll $a, b$ and carotenoids were expressed in $\mathrm{mg} \mathrm{g}^{-1}$ of fresh matter (FM).

At this same evaluation period (75 DAS), the gas exchanges of cotton plants were measured by determining stomatal conductance $\left(g s-\mathrm{mol} \mathrm{H}_{2} \mathrm{O} \mathrm{m}^{-2} \mathrm{~s}^{-1}\right), \mathrm{CO}_{2}$ assimilation rate $(A$ -

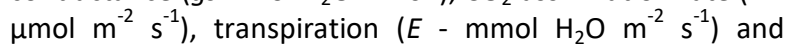
internal $\mathrm{CO}_{2}$ concentration $\left(\mathrm{Ci}-\mu \mathrm{mol} \mathrm{mol}{ }^{-1}\right)$, using a portable infrared gas analyzer (IRGA), model LCPro+ Portable Photosynthesis System ${ }^{\circledR}$. These data were used to quantify the instantaneous water use efficiency (WUEi) $(A / E)$ [ $(\mu \mathrm{mol}$ $\left.\mathrm{m}^{-2} \mathrm{~s}^{-1}\right)\left(\mathrm{mmol} \mathrm{H}_{2} \mathrm{O} \mathrm{m}^{-2} \mathrm{~s}^{-1}\right)^{-1}$ ] and instantaneous carboxylation efficiency (EiCi) $(A / C i)\left[\left(\mu \mathrm{mol} \mathrm{m} \mathrm{m}^{-2}\right)(\mu \mathrm{mol}\right.$ $\left.\mathrm{mol}^{-1}\right)^{-1}$.

\section{Statistical analysis}

The collected data were subjected to analysis of variance by $\mathrm{F}$ test. When significant, means comparison test (Tukey test at 0.05 probability level) was carried out for the combinations of fertilization with $\mathrm{N}$ and $\mathrm{K}$ and polynomial regression analysis was performed for water salinity levels, using the statistical software SISVAR-ESAL.

\section{Conclusion}

There is degradation in the contents of chlorophyll $a$ and $b$ and in cotton growth, but the cultivar BRS 368 RF sharply increases the biosynthesis of carotenoids at 75 days after sowing. Nitrogen and potassium supply in the combination of $100 / 75 \%$ of respective recommendations leads to increase in the height of cotton cv. BRS 368 RF. The supply of nitrogen in combination with potassium does not alleviate the deleterious effects of salt stress on gas exchange, photosynthetic pigments and growth of cotton.

\section{Acknowledgements}

To the National Program of Post-Doctorate (PNPD/CAPES/UFCG), for granting the scholarship to the second author and to the National Institute of Science and Technology in Salinity - INCTSal, for funding the project.

\section{References}

Ambede JG, Netondo GW, Mwai GN, Musyimi DM (2012) $\mathrm{NaCl}$ salinity affects germination, growth, physiology, and biochemistry of bambara groundnut. Braz J Plant Physiol. 24:151-160.

Arnon DI (1949) Copper enzymes in isolated cloroplasts: polyphenoloxidases in Beta vulgaris. Plant Physiol. 24:115.

Associação Brasileira de Produtores de Algodão (ABRAPA). A cadeia do algodão brasileiro - Safra 2012/2013: Desafios e estratégias / Organizadores: Marcos Fava Neves e Mairun Junqueira Alves Pinto. Brasília: Associação Brasileira dos Produtores de Algodão, 2013.
Ayers RS; Westcot DW (1999) Water quality for agriculture. Rome: FAO, 97p. (FAO. Irrigation and Drainage Peper, 29)

Bezerra IL, Gheyi HR, Nobre RG, Lima GS de, Santos JB dos, Fernandes PD (2018) Interaction between soil salinity and nitrogen on growth and gaseous exchanges in guava. Rev Ambient Água.13:1-12.

Brasil. Ministério da Agricultura, Pecuária e Abastecimento. Cadeia produtiva do algodão/Ministério da Agricultura, Pecuária e Abastecimento, Secretaria de Política Agrícola, Instituto Interamericano de Cooperação para a Agricultura. Antônio Márcio Buainain e Mário Otávio Batalha (coordenadores), Pedro Vieira Junior, Sheila Ferreira Leite. - Brasília: IICA: MAPA/SPA, 2007.

Campos ML de O, Hsie BS de, Granja JA de A, Correia RM, Almeida-Cortez JS de, Pompelli M F (2012) Photosynthesis and antioxidant activity in Jatropha curcas L. under salt stress. Braz J Plant Physiol. 24:55-67.

Companhia Nacional de Abastecimento (CONAB). Perspectivas para agropecuária, Brasília. v 4. 132p. 2017.

Donagema, GK, Campos DVB de, Calderano SB, Teixeira WG, Viana JHM (2011) Manual de métodos de análise de solo. 2. ed. Rio de Janeiro, RJ: Embrapa Solos. 230 p.

Empresa Brasileira de Pesquisa Agropecuária (EMBRAPA). Centro Nacional de Pesquisa de Algodão (Campina Grande, PB). Algodão colorido: "Tecnologia Embrapa para a geração de emprego e renda na agricultura familiar do Brasil". 2017. 2p. (Embrapa-CNPA, Circular Técnico, 17).

Gonçalves ER, Ferreira VM, Silva JV, Endres L, Barbosa TP, Duarte WG (2010) Trocas gasosas e fluorescência da clorofila $a$ em variedades de cana-de-açúcar submetidas à deficiência hídrica. Rev Bras Eng Agríc Ambient. 14:378386.

Gratão PL, Polle A., Lea PJ, Azevedo RA (2005) Making the life of heavy metal-stressed plants a little easier. Funct Plant Biol. 32:481-494.

Grimes, DW, Carter, LM. (1969) A linear rule for direct nondestructive leaf área measurements. Agron J. 61:477479.

Gurgel MT, Gheyi HR, Oliveira FHT (2010) Acúmulo de matéria seca e nutrientes em meloeiro produzido sob estresse salino e doses de potássio. Rev Ciênc Agron. 41:18-28.

Jouyban Z (2012) The effects of salt stress on plant growth. J Eng Appl Sci. 2:7-10.

Lima GS de, Dias AS, Gheyi HR, Soares LA dos A, Nobre RG, Sá FV da S, Paiva EP de (2017) Emergence,morphophysiology and flowering of colored-fiber cotton (Gossypium hirsutum L.) submitted to different nitrogen levels and saline water stress irrigation. Aust J Crop Sci. 11:897-905.

Lima GS de, Nobre RG, Gheyi HR, Soares LA dos A, Silva AO da (2014) Physiology, growth and yield of castor bean under salt stress and nitrogen doses in phenophases. Idesia. 32:91-99.

Matsumoto SN, Araújo G da S, Viana AES (2013) Growth of sweet basil depending on nitrogen and potassium doses. Hortic Bras.31:489-493.

Meurer EJ (2006) Potássio. In: Fernandes MS. (ed.) Nutrição mineral de plantas. Viçosa: Sociedade Brasileira de Ciência do Solo, p.281-299.

Morais PLD de, Dias N da S, Oliveira AM de, Sousa Neto ON de, Sarmento JDA, Gonzaga MIS (2018) Effects of nutrient solution salinity on the physiological performance of 
melon cultivated in coconut fiber. Rev Caatinga. 31:713-718. Novais RF, Neves JCL, Barros NF (1991) Ensaio em ambiente controlado. In: Oliveira AJ, Garrido WE, Araújo JD de, Lourenço $S$. Métodos de pesquisa em fertilidade do solo. Embrapa SEA, Brasília, Brasil. p.189-253.

Oliveira FA, Medeiros JF, Oliveira FRA, Freire AG, Soares LCS (2012) Produção do algodoeiro em função da salinidade e tratamento de sementes com regulador de crescimento. Rev Ciênc Agron. 43:279-287.

Ouyang W, Struik PC, Yin X, Yang J (2017) Stomatal conductance, mesophyll conductance, and transpiration efficiency in relation to leaf anatomy in rice and wheat genotypes under drought. J Exp Bot. 68:5191-5205.

Richards LA (1954) Diagnosis and improvement of saline and alkali soils, Washington: U.S, Department of Agriculture.160p. Handbook 60.

Sayyad-Amin P, Jahansooz MR, Borzouei A, Ajili F (2016) Changes in photosynthetic pigments and chlorophyll-a fluorescence attributes of sweet-forage and grain sorghum cultivars under salt stress. J Biol Phys. 42:601-620.

Silva EN, Silveira JAG, Rodrigues CRF, Lima CS, Viégas RA (2009). Contribuição de solutos orgânicos e inorgânicos no ajustamento osmótico de pinhão-manso submetido à salinidade. Pesq Agropec Bras. 44:437-445.
Silva JL de A, Alves SSV, Nascimento IB do, Medeiros JF de, Targino AJ de O, Linhares PSF (2014) Teores foliares no pimentão submetido a estresse salino em diferentes solos. Agropec Cient Semiárid. 10:77-82.

Soares, LA dos A, Fernandes PD, Lima GS de, Suassuna JF, Pereira RF (2018) Gas exchanges and production of colored cotton irrigated with saline water at different phenological stages. Rev Ciênc Agron. 49:239-248.

Sousa GG de, Rodrigues V dos S, Soares S da C, Damasceno I N, Fiusa J N, Saraiva SEL (2018). Irrigation with saline water in soybean (Glycine max (L.) Merr.) in a soil with bovine biofertilizer. Rev Bras Eng Agríc Ambient. 22:604-609.

Tabot PT, Adams JB (2013) Early responses of Bassia diffusa (Thunb.) Kuntze to submergence for different salinity treatments. S Afr J Bot. 84:19-29.

Taiz L, Zeiger E. Moller IM, Murphy A. Fisiologia vegetal. 6. ed. Porto Alegre: Artmed, 2017. 918p.

Time A, Garrido M, Acevedo E (2018) Water relations and growth response to drought stress of Prosopis tamarugo Phil. A review. J. Soil Sci Plant Nutr.18:329-343.

Venkatesan S, Ganapthy MNK (2004) Nitrate reductase activity in tea as influenced by various levels or nitrogen and potassium fertilizers. Commun Soil Sci Plant Anal. 35:1283-1291. 